\title{
交互累積法による機能性ナノ薄膜及びミクロカプセルの開発
}

\author{
佐 藤 勝 彦
}

\section{Development of Functional Multilayer Nanofilms and Microcapsules Based on Layer-by-Layer Deposition Techniques}

\author{
Katsuhiko Sato \\ Graduate School of Pharmaceutical Sciences, Tohoku Unicersity; \\ 6-3 Aoba, Aramaki, Aoba-ku, Sedai 980-8578, Japan.
}

(Received May 28, 2015)

\begin{abstract}
Functional multilayer thin films have been prepared by layer-by-layer (LbL) deposition for the development of sensors, separators, and drug delivery systems. In particular, glucose-sensitive LbL films have been widely studied for use as glucose sensors and in glucose-triggered drug delivery systems. In this work, I report on glucose-sensitive LbL films that consist of concanavalin A (ConA), phenylboronic acid (PBA), and glucose oxidase (GOx). ConA/glycogen LbL films were prepared by LbL deposition of ConA and glycogen through a lectin-sugar interaction. Similarly, PBA-modified poly (amidoamine) dendrimer/poly (vinyl alcohol) (PVA) LbL films were prepared through cyclic boronate ester bonds. Both types of films decomposed in the presence of glucose, by the competitive binding of glucose, although these LbL films did not show a satisfactory response to millimolar concentrations of glucose under physiological conditions. PBA-modified poly (allylamine hydrochloride) and PVA films were prepared on a GOx-modified quartz slide. The LbL film was stable over a wide $\mathrm{pH}$ range, from 3.0 to 9.0, in the absence of glucose. In contrast, the film decomposed upon exposure to $0.1-10 \mathrm{~mm}$ glucose solutions for $60 \mathrm{~min}$ at $\mathrm{pH}$ 7.4. The glucose-induced decomposition of the film can be explained by the scission of the carbon-boron bond of the PBA residues by hydrogen peroxide, which was produced through the GOx-catalyzed oxidation of glucose. These results suggest this multilayer film may be useful for the development of glucose-sensitive drug delivery systems.
\end{abstract}

Key words_-layer-by-layer ( $\mathrm{LbL}$ ) film; microcapsule; glucose response; phenylboronic acid

\section{1. 交互累積膜法とは}

交互累積膜法は薄膜作製技術の 1 つであり，金属 や石英などの基板をポリカチオンとポリアニオンの 溶液に交互にひたすことにより静電的相互作用に よって基板表面にナノメーターレベルの多層膜を作 製する (Fig. 1). 1) 近年では，多層膜形成の駆動力 として静電的相互作用のほかにも糖ーレクチン結 合2)やアビジンービオチン結合3)などの生物学的な親 和性及びシクロデキストリンなどを利用したホス トーゲスト結合4)や水素結合などの弱(結合5)も利用 されている. このように相互に結合する 2 種以上の 高分子を用いることで累積膜を作製することができ

東北大学大学院薬学研究科（干980-8578 仙台市青葉区 荒巻字青葉 6-3)

e-mail: satok@m.tohoku.ac.jp

本総説は, 平成 26 年度日本薬学会東北支部奨励賞の受 賞を記念して記述したものである.
る.この方法は, 薄膜を構成する材料を自由に選択 できること，特殊な技術や装置を必要としないこ と，すべての工程を水溶液中及び温和な条件で行え ることなどの利点があり幅広い分野で利用されてい る.

また，交互累積膜法によりミクロカプセルを作製 することができる. ${ }^{6,7)}$ はじめに，ナノ〜マイクロ メートルサイズの球状微粒子の表面に累積膜を被覆 してカプセル膜を形成し，その後，微粒子を適当な 方法で溶解除去することにより中空のカプセルとす る (Fig. 2)。累積膜と同様の利点を有し生体試料 を利用した機能性カプセルの開発に有用であ

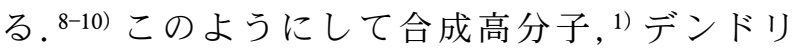
マー, 11) 超分子, 12) タンパク質, 13) 微粒子14)など様 々な材料から累積膜が作製され, 光学及び電気化学 センサーの表面修飾, ${ }^{14,15)} \mathrm{pH}$ やイオンなどの刺激 応答, 16,17$)$ 薬物放出制御 ${ }^{18)}$ のような機能性ナノ薄膜 


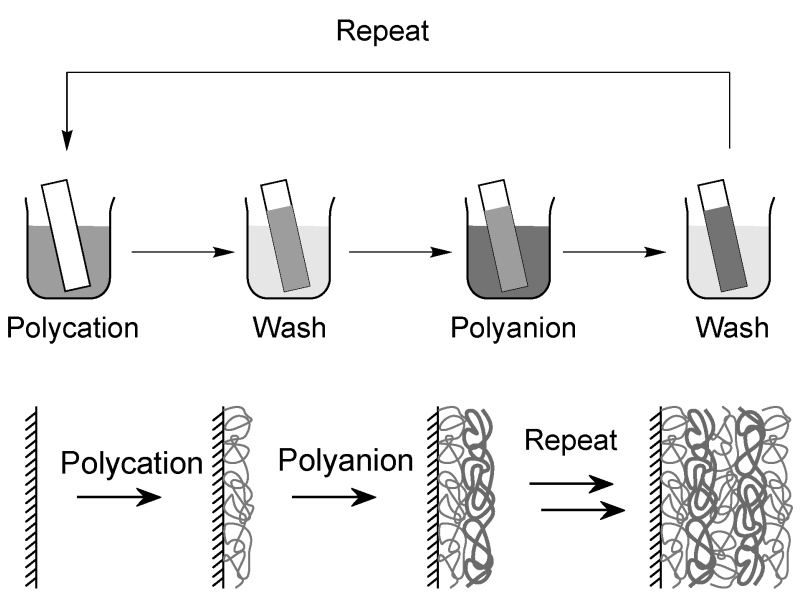

Fig. 1. An Experimental Procedure of Layer-by-Layer Deposition of Thin Films

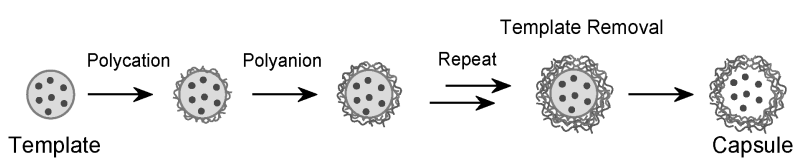

Fig. 2. Preparation Process of Layer-by-Layer Microcapsule

やミクロカプセルの開発に利用されている. ${ }^{19,20)}$ 筆 者はこれまで交互累積膜法を用いて種々の機能性薄 膜の開発を行ってきた．本稿では特にグルコース刺 激によって分解する累積膜及びカプセルについて紹 介する.

2. Concanavalin A を用いたグルコース応答交 互累積膜

コンカナバリン A (concanavalin A; ConA) は夕 チナタマメなどに含まれる分子量 104000 の糖結合 タンパク質（レクチン）であり，4 量体の各サブユ ニットに 1 力所の糖結合部位を有し糖類と可逆的に 結合することが知られている (Fig. 3)。既に ConA のこのような性質を利用した糖センサーが多数報告 されており, 6,21-23) 筆者も ConA と糖鎖の結合を利 用することで累積膜を作製することができると考え た．また，この結合は可逆であることからグルコー スの競合作用による膜の分解応用が期待できた。つ まり，累積膜にグルコースを添加すると，累積膜内 部で ConA と結合している糖鎖がグルコースと置 換するため, 累積膜形成の駆動力である ConA と 糖鎖間の結合が切断され累積膜が分解すると考えた (Fig. 4).

はじめに, ConA と累積膜を形成することのでき る糖鎖について検討を行つたところ，グリコーゲン

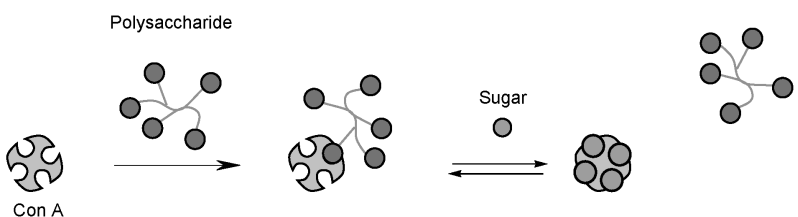

Fig. 3. Complexation between Concanavalin A and Sugar

（glycogen；Gly）を用いることで良好な累積膜の形 成が確認できた. ${ }^{2)}$ Gly はグルコースユニットが連 なつた糖鎖であり ConA と特異的に結合し凝集す ることが知られている. また，累積膜の調製に用い る Gly 溶液に $10 \mathrm{mM}$ のグルコースを共存させると 累積膜は形成しなかった。このことはグルコースの 競合作用により ConA-Gly 結合の形成が阻害され ている結果であり, ConA/Gly 累積膜形成の駆動力 が疎水的吸着などの非特異的な吸着ではなく ConA 由来のレクチン結合に基づいていることを示してい る.

次に, ConA/Gly 累積膜の糖応答性を調査した。 Figure 5 は累積膜を糖溶液に浸漬したときの残存率 を表している。 その結果, ConA/Gly 累積膜の分解 速度は添加した糖類と ConA との親和性の強さ, 及び濃度に依存した。すなわち, ConA と非常に高 い親和性を持つメチルマンノースとメチルグルコー スは添加後の 10 分間でそれぞれ $1 \mathrm{~mm}$ 及び $5 \mathrm{~mm}$ において高い応答性を示した（ConA とメチルマン ノース及びメチルグルコースの結合定数はそれぞれ $\left.2.1 \times 10^{4} \mathrm{M}^{-1}, \quad 4.9 \times 10^{3} \mathrm{M}^{-1}\right) .{ }^{24)}$ また，マンノース も高い親和性を持つことから Gly とよく置換する ことが推測でき, グルコースよりも低濃度で累積膜 は分解した（ConA とマンノース及びグルコース結 合定数はそれぞれ $\left.2.2 \times 10^{3} \mathrm{M}^{-1}, 0.8 \times 10^{3} \mathrm{M}^{-1}\right) .{ }^{25)}$ 累積膜をほぼ分解するためにマンノースとグルコー スでそれぞれ $20 \mathrm{~mm}$ 及び $50 \mathrm{~mm}$ を必要とした。一 方, ConA/Gly 累積膜はガラクトースに対してはほ とんど分解しなかった。この理由として, ConA は マンノース結合型レクチンであるためガラクトース は ConA とほとんど結合することができず ConAGly 結合に影響しなかったと考えられる。これらの 結果は, 明らかに ConA と糖の親和性の程度に依 存して ConA/Gly 累積膜が分解していることを示 している. 


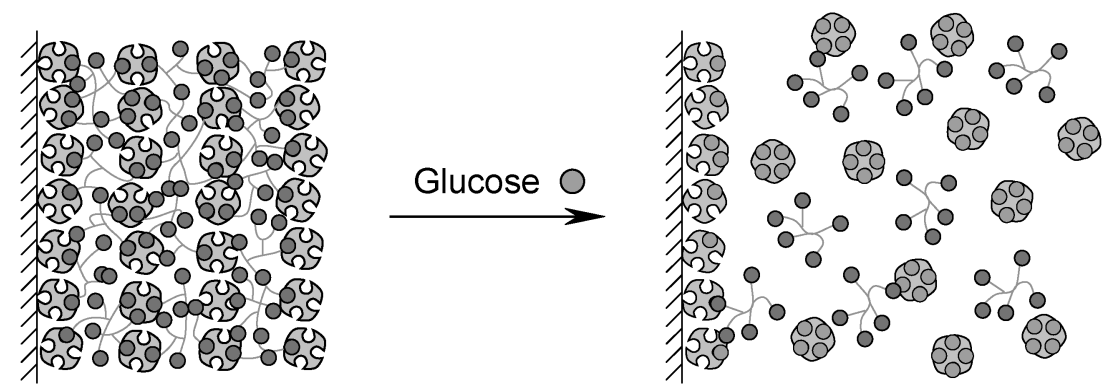

Fig. 4. Schematic Illustration of Sugar-induced Disintegration of Concanavalin A/Sugar-polymer Multilayer Assembly
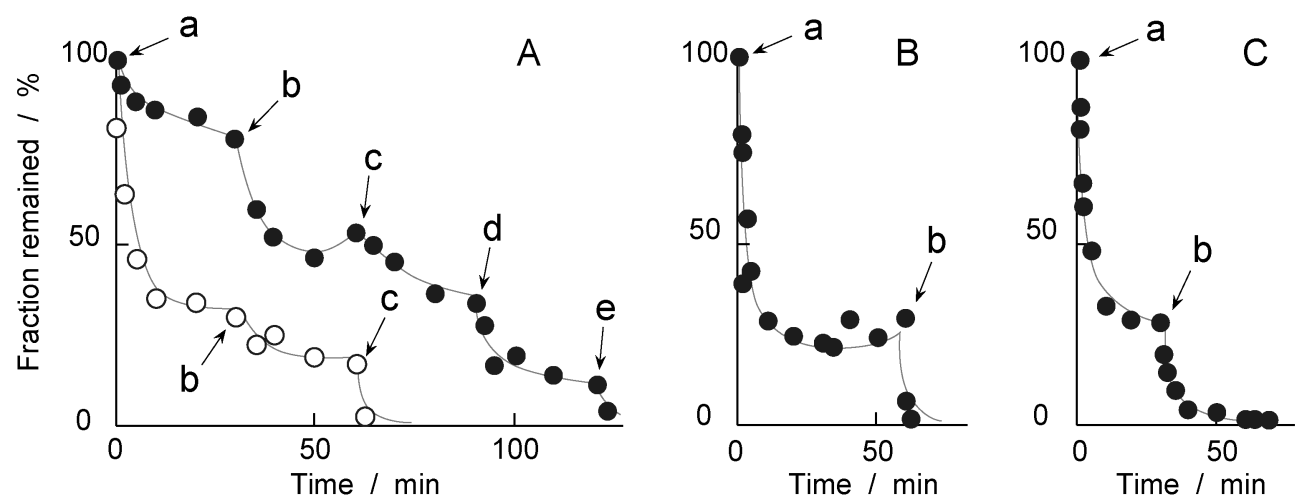

Fig. 5. Effects of the Concentration of Glucose (in panel A), Mannose ( $\bigcirc$ in panel A), Methyl-glucose (panel B), and Methylmannose (panel C) on the Rate of Disintegration of the ConA-Glycogen Multilayer Film (10 bilayers)

The concentration of the sugar was follows: (panel A) (a) $5 \mathrm{~mm}$, (b) $10 \mathrm{~mm}$, (c) $20 \mathrm{~mm}$, (d) $50 \mathrm{~mm}$, and (e) $100 \mathrm{~mm}$; (panel B) (a) $5 \mathrm{~mm}$ and (b) $20 \mathrm{~mm}$; (panel C) (a) $1 \mathrm{~mm}$ and (b) $2 \mathrm{~mm}$.

\section{Concanavalin A を用いたグルコース応答ミ}

\section{クロカプセル}

グルコースに応答する交互累積膜の調製ができた ので，これをカプセル膜としたミクロカプセルの作 製及び糖刺激によるインスリン放出応答を調査し た. ${ }^{26)}$ はじめに，カプセル作製のためテンプレート として用いる微粒子について検討を行つた。通常, 交互累積膜法によるカプセル作製にはメラミンーホ ルムアルデヒド樹脂や二酸化ケイ素の微粒子が用い られるが，それぞれ強酸及び HF のような過酷な溶 解条件を必要とするため機能性タンパク質のカプセ ル化には適していない。 また，これらの微粒子を用 いた場合にはインスリンを効果的に封入することが 困難である，そこで，筆者は $\mathrm{CaCO}_{3}$ 粒子を用いる ことにした. 条件検討を行い, 粒形制御のためのポ リスチレンスルホン酸を含む $\mathrm{Na}_{2} \mathrm{CO}_{3}$ 水溶液とイン スリンを含む $\mathrm{CaCl}_{2}$ 水溶液を混合することで直径 およそ $2 \mu \mathrm{m}$ のインスリンを内部に取り込んだ $\mathrm{CaCO}_{3}$ 粒子を調製することに成功した. $\mathrm{CaCO}_{3}$ 粒 子はカプセル膜被膜後に緩衝溶液中での ethylenediaminetetraacetic acid（EDTA）処理で溶 解除去することが可能である. ${ }^{27)} こ の$ 粒子を鋳型と してカプセル作製を行ったところ, 残念ながら ConA と Gly のみの累積膜では強度不足であり EDTA 処理に耐えることができなかった。そこ で，カプセル膜の内外に補強のためのポリエチレン イミン及びポリスチレンスルホン酸のような高分子 電解質層を補うことで ConA/Gly 層を含むカプセ ルの作製に成功した。このカプセルの糖応答性は累 積膜の場合と同様であり糖の種類及び濃度に依存し た。グルコースに対しては 50-100 mM 程度で分解 し，それに伴うインスリンの放出が確認できた。こ れらの応答は明らかに ConA とグルコースとの親 和性に由来しておりレクチン活性を維持したまま ConA をカプセル膜に導入できたことを示してい る。この手法は生体試料を用いたミクロカプセルの 開発に有用であり，実際に筆者らはこの研究のほか にもアビジンや酵素をカプセル膜に導入したカプセ ルの開発に成功している. ${ }^{28)}$ 
<smiles>OB(O)c1ccccc1</smiles><smiles>[R]C(O)C([R])O</smiles><smiles>[R]C1OB(O)OC1([R])c1ccccc1</smiles><smiles>C[B-]1(O)OC2C(O)OC(CO)C(O)C2O1</smiles>

Phenylboronic acid

Fig. 6. PBA Complexation with Diol<smiles>OB(O)c1ccccc1</smiles><smiles>[R]C(O)C([R])O</smiles><smiles>[R]C1O[B-](O)(c2ccccc2)OC1[R]</smiles>

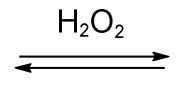<smiles>Oc1ccccc1</smiles>

Phenylboronic acid

Fig. 7. Oxidation of Boronate Ester to Phenol by $\mathrm{H}_{2} \mathrm{O}_{2}$

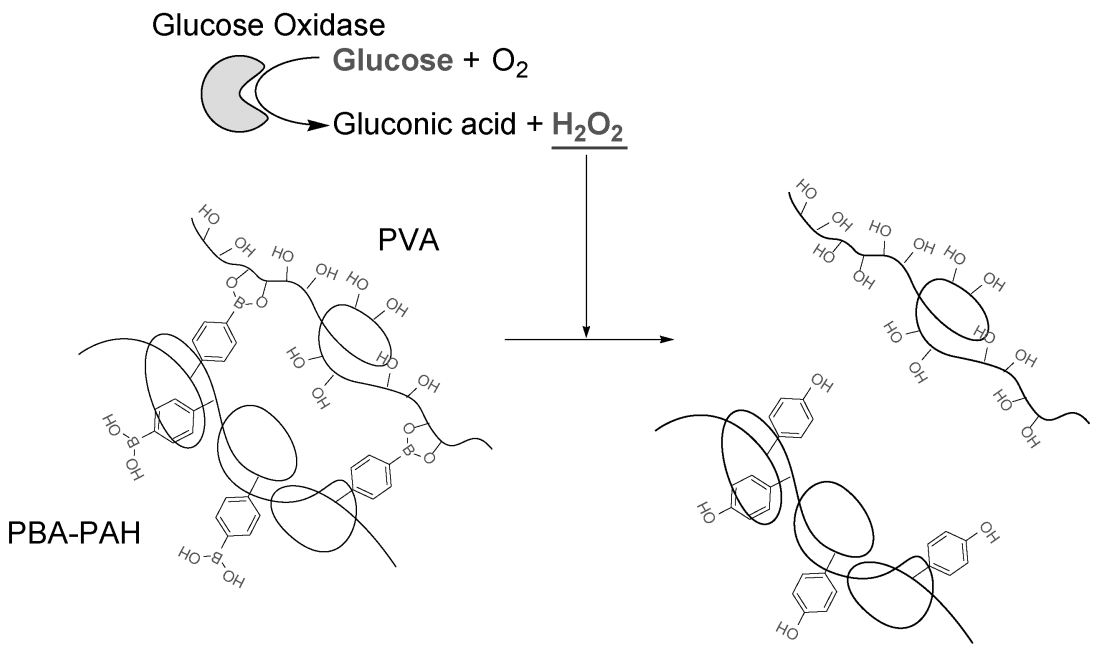

Fig. 8. A Schematic Illustration of Glucose-induced Decomposition of PBA-PAH/PVA Multilayer Film

\section{Phenylboronic acid を用いたグルコース応答} 薄膜

レクチンや酵素などの機能性タンパク質を分子認 識素子としたグルコース応答薄膜が多数報告されて いる．生体試料を用いることで高い感度と特異性が 得られるが，長期の使用において生理的条件では活 性の低下は避けられず性能の低下を避けることはで きない. また，コストの点も問題である。このよう な問題を回避するため低分子化合物を分子認識素子 とすることで安定で安価なシステムを開発すること が期待できる。フェニルボロン酸（phenylboronic acid；PBA）はジオール構造を持つ化合物と環状エ
ステル結合を形成する．この結合は可逆的なため競 合物質であるグルコースなどの糖類により置換され 再分割される (Fig. 6)。既にPBA のこのような性 質は糖類のセンシングに利用されており，これまで に蛍光変化や色調変化としてグルコースを検出する PBA 誘導体など数多く報告されている. ${ }^{29-32)}$

そこで, PBA とジオールとの結合を駆動力とし た交互累積膜の調製と糖応答性について調査を行つ た. ${ }^{33)}$ 種々の条件を検討したところ PBA を末端ア ミンに修飾した PAMAM デンドリマー（PBA-D） と, ジオール構造を持つ高分子としてポリビニルア ルコール（polyvinyl alcohol; PVA）を用いること 


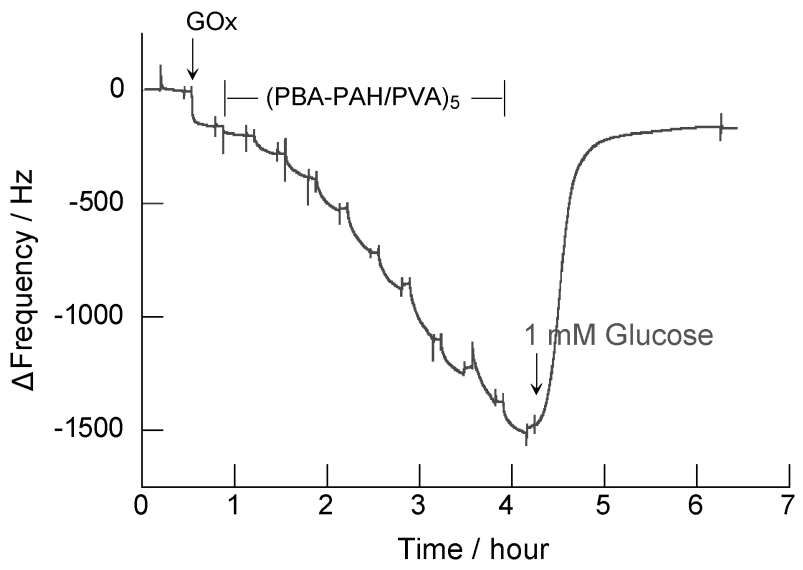

Fig. 9. Typical QCM Response for the Preparation of GOx (PBA-PAH/PVA) 5 Multilayer Film and Its Glucose-induced Decomposition at pH 7.4 in 10 mM HEPES Buffer Solution

で累積膜を作製することができた。このPBA-D/ PVA 累積膜の糖応答性はフルクトースの置換効果 により $10 \mathrm{mM}$ において完全な分解が確認できた.

しかし，グルコースに対しては分解率は数\%のみで あった．理由として PBA とグルコースの親和性が 小さいことこと（フルクトース $160 \mathrm{M}^{-1}$, グルコー ス $\left.4.6 \mathrm{M}^{-1}\right)^{34)}$ が挙げられる. 応答性改善のためグ ルコース親和性のより強いPBA 誘導体を用いて同 様の検討を行ったがそれでも十分な分解応答は得ら れなかった。

5. $\mathrm{H}_{2} \mathrm{O}_{2}$ による PBA の酸化反応を利用したグル コース応答累積膜

PBA とグルコースの親和性が小さいため競合作 用による膜分解は起こらなかった。 そこで，PBA が $\mathrm{H}_{2} \mathrm{O}_{2}$ によりフェノールへと酸化される化学反応 に注目した（Fig. 7)。この反応は $\mathrm{H}_{2} \mathrm{O}_{2}$ に対して中 性の水溶液中においても鋭敏に進行するため, 活性 酸素種の検出及び薬物送達システムの開発などにも 用いられている. ${ }^{35-39)}$ この反応とグルコースオキシ ダーゼ（glucose oxidase; GOx）の酵素反応を組み 合わせたグルコース応答機構を検討した，Figure 8 に示すように，GOx によりグルコースから生成さ れた $\mathrm{H}_{2} \mathrm{O}_{2}$ が累積膜形成の駆動力であるボロン酸エ ステル結合を開裂することにより膜が分解すること を期待した.

はじめに PBA が $25 \%$ 程度修飾されたポリアリル アミン（PBA-PAH）と PVAより累積膜を作製し $\mathrm{H}_{2} \mathrm{O}_{2}$ に対する分解応答について調査を行つた. ${ }^{40)}$ その結果, この薄膜は $\mathrm{pH}$ 変化やイオン強度, 競合 物質である糖類に対して安定であるが， $0.1 \mathrm{mM}$ 程 度の $\mathrm{H}_{2} \mathrm{O}_{2}$ に対して鋭敏な分解応答を示した。 そこ で，GOx 層を最内層に加えた累積膜を作製しグル コース応答の調査を行った. Figure 9 に GOx を含 むPBA-PAH / PVA 累積膜の作製過程，及び $\mathrm{pH}$ 7.4 緩衝溶液中での $1 \mathrm{~mm}$ グルコース添加時の水晶 振動子ミクロバランス法測定結果を示す。共振周波 数変化 $(\Delta \mathrm{F})$ の減少は基板上への物質の吸着, 増
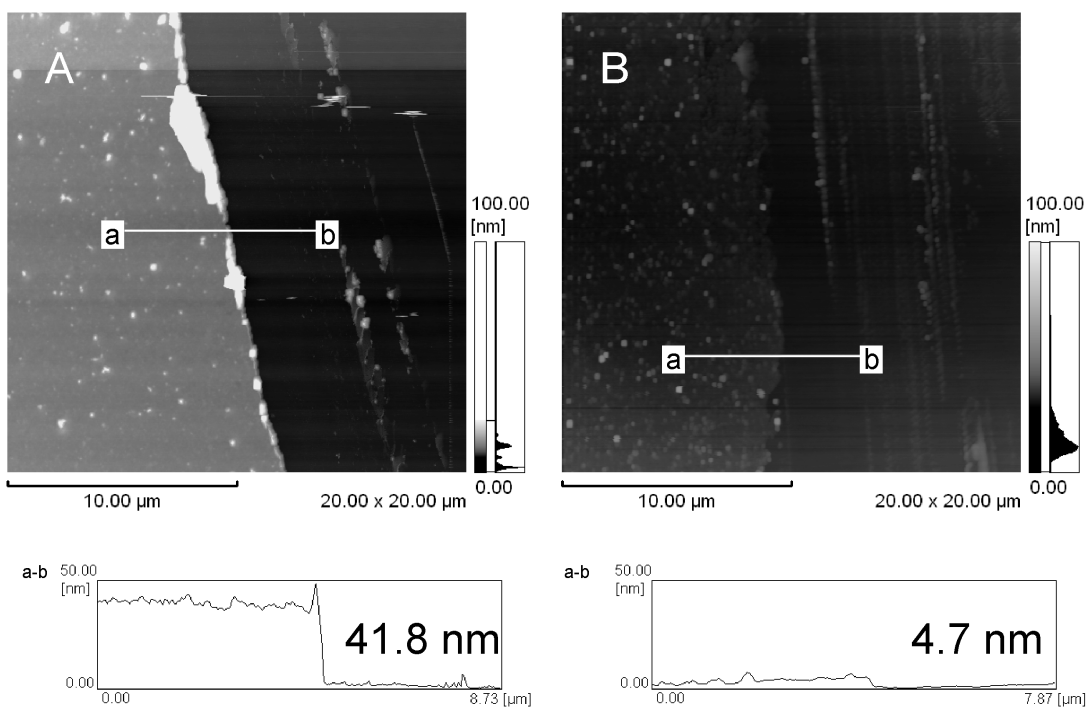

Fig. 10. AFM Images of GOx (PBA-PAH/PVA) ${ }_{10}$ Film before (A) and after (B) Exposure to $10 \mathrm{~mm}$ Glucose for $60 \mathrm{~min}$ at $\mathrm{pH} 7.4$ The images were recorded in dry state. 
加は基板からの剥離を表す。はじめ, GOx の添加 によって $\Delta \mathrm{F}$ の減少がみられ水晶振動子上への GOx の層の形成が確認できる。その後のPBA$\mathrm{PAH}$ と PVA の積層操作でも同様に $\Delta \mathrm{F}$ が減少し GOx を含む PBA-PAH/PVA 累積膜が調製できて

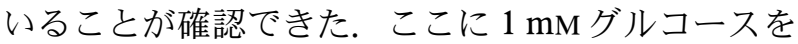
添加すると $\Delta \mathrm{F}$ の急激な増加がみられ，グルコース の添加による膜の分解応答が確認できた．GOx 層 と次の PBA-PAH 層は静電的相互作用により結合 しているため $\mathrm{H}_{2} \mathrm{O}_{2}$ により崩壊しないことを考慮す ると PBA とジオールのエステル結合を駆動力とし ている累積膜層は完全に分解していると見積もられ る. 同様に AFM 観察からも生理条件下におけるグ ルコースに対する膜の分解挙動を確認することがで きた（Fig. 10)。この累積膜の膜厚はおよそ $42 \mathrm{~nm}$ 程度であるが，グルコース処理により $4 \mathrm{~nm}$ まで減 少した.

\section{6. おわりに}

本稿で紹介したように，交互累積膜は合成高分子 やタンパク質などを一層ずつ累積して薄膜あるいは カプセルとする方法で, 材料の選択の幅が広く, 薄 膜の構造制御という点でも有用性が高い方法であ る.この方法により, 機能性ナノ薄膜やミクロカプ セルの開発のための多彩なアイデアを実現すること が可能であり今後の展開が期待できる.

\section{謝辞本稿で紹介した研究はすべて東北大学大} 学院薬学研究科で行われました。これらの研究に関 しご指導頂きました安齋順一教授に御礼申し上げま す.

利益相反＼cjkstart開示すべき利益相反はない.

\section{REFERENCES}

1) Decher G., Science, 277, 1232-1237 (1997).

2) Sato K., Imoto Y., Sugama J., Seki S., Inoue H., Odagiri T., Hoshi T., Anzai J., Langmuir, 21, 797-799 (2005).

3) Inoue H., Sato K., Anzai J., Biomacromolecules, 6, 27-29 (2005).

4) Wang Z., Feng Z., Gao C., Chem. Mater., 20, 4194-4199 (2008).

5) Tomita S., Sato K., Anzai J., J. Colloid Interf. Sci., 326, 35-40 (2008).
6) Sato K., Anzai J., Anal. Bioanal. Chem., 384, 1297-1301 (2006).

7) Donath E., Sukhorukov G. B., Caruso F., Davis S. A., Möhwald H., Angew. Chem. Int. Ed., 16, 2202-2205 (1998).

8) Tong W., Gao C., J. Mater. Chem., 18, 37993812 (2008).

9) Mercato L. L., Ferraro M. M., Baldassarre F., Mancarella S., Greco V., Rinaldi R., Leporatti S., Adv. Colloid Interface Sci., 207, 139-154 (2014).

10) Sato K., Hoshina S., Anzai J., Polym. Bull., 68, 891-900 (2012).

11) Sato K., Anzai J., Molecules, 18, 8440-8460 (2013).

12) Sato K., Suzuki I., Anzai J., Langmuir, 19, 7406-7412 (2003).

13) Takahashi S., Sato K., Anzai J., Anal. Bioanal. Chem., 402, 1749-1758 (2012).

14) Pingarrón J. M., Yáñez-Sedeño P., GonzálezCortés A., Electrochim. Acta, 53, 5848-5866 (2008).

15) Zhao W., Xu J., Chen H., Electroanalysis, 18, 1737-1748 (2006).

16) Hashide R., Yoshida K., Hasebe Y., Takahashi S., Sato K., Anzai J., Colloid Surf. B, 89, 242-247 (2012).

17) Sato K., Kodama D., Naka Y., Anzai J., Biomacromolecules, 7, 3302-3305 (2006).

18) Sato K., Yoshida K., Takahashi S., Anzai J., Adv. Drug Deliv. Rev., 63, 809-821 (2011) .

19) Ariga K., Yamauchi Y., Rydzek G., Ji Q., Yonamine Y., Wu K. C.-W., Hill J. P., Chem. Lett., 43, 36-68 (2014).

20) Borges J., Mano J. F., Chem. Rev., 114, 8883-8942 (2014).

21) Sato K., Kodama D., Anzai J., Anal. Bioanal. Chem., 386, 1899-1904 (2006).

22) Hayashida O., Hamachi I., Chem. Lett., 32, 632-633 (2003).

23) Ibey B. L., Beier H. T., Rounds R. M., Coté G. L., Anal. Chem., 77, 7039-7046 (2005) .

24) Schwarz F. P., Puri K. D., Bhat R. G., Surolia A., J. Biol. Chem., 268, 7668-7677 (1993) .

25) Mandal D. K., Kishore N., Brewer C. F., Biochemistry, 33, 1149-1156 (1994) .

26) Sato K., Kodama D., Endo Y., Anzai J., $J$. Nanosci. Nanotechnol., 9, 386-390 (2009).

27) Sato K., Seno M., Anzai J., Polymers, 6, 
2157-2165 (2014).

28) Endo Y., Sato K., Sugimoto K., Anzai J., J. Colloid. Interf. Sci., 360, 519-524 (2011).

29) Sato K., Nakajima T., Yasukawa Y., Anzai J., Polym. Bull., 65, 807-814 (2010) .

30) Kawanishi T., Romey M. A., Zhu P. C., Holody M. Z., Shinkai S., J. Fluoresc., 14, 499-512 (2004).

31) Shibata H., Heoa Y. J., Okitsua T., Matsunaga Y., Kawanishi T., Takeuchia S., Proc. Natl. Acad. Sci. USA, 107, 17894-17898 (2010).

32) Asher S. A., Alexeev V. L., Goponenko A. V., Sharma A. C., Lednev T. K., Wilcox C. S., Finegold D. N., J. Am. Chem. Soc., 125, 3322-3329 (2003).

33) Watahiki R., Sato K., Suwa K., Niina S., Egawa, Y., Seki T., Anzai J., J. Mater. Chem. B,
2, 5809-5817 (2014).

34) Springsteen G., Wang B., Tetrahedron, 58, 5291-5300 (2002).

35) Sato K., Abe E., Takahashi M., Anzai J., $J$. Colloid Interf. Sci., 432, 92-97 (2014).

36) Dickinson B. C., Huynh C., Chang C. J., J. Am. Chem. Soc., 132, 5906-5915 (2010).

37) Song C., Ji R., Du F., Li Z., Macromolecules, 46, 8416-8425 (2013).

38) Broaders K. E., Grandhe S., Fréchet J. M. J., J. Am. Chem. Soc., 133, 756-758 (2011).

39) Lux C. G., Joshi-Barr S., Nguyen T., Mahmoud E., Schopf E., Fomina N., Almutairi A., J. Am. Chem. Soc., 134, 15758-15764 (2012).

40) Sato K., Takahashi M., Ito M., Abe E., Anzai J., Langmuir, 30, 9247-9250 (2014) . 